\title{
BOSNA-HERSEK SORUNUNDA ULUSLARARASI YARGININ ROLÜ
}

\author{
Prof. Dr. Hüseyin PAZARCI*
}

\section{Giriş}

Uluşararası krizlere müdahalede uluslararası hukukun sağladı̆̆ı olanakları değerlendirdiğimizde başlıca üç değişik yöntemin varlığı gözler önüne serilmektedir. Bunlar, i) diplomatik yöntemler, ii) uluslararası ơrgütlerin müdahaleleri, iii) uluslararası yargının müdahaleleri.

Bosna-Hersek sorununun çözümüne ilişkin olarak taraflar arasında görüşmelerden başlayarak üçüncü Devletlerin katılımı ile sağlanan dostça girişim ve arabuluculuk girişimlerini de içeren çok çeşitli yollara başvurulduğu hepimizin malumudur. Nitekim, ABD'nin girişimiyle Boşnak, Sırp ve Hırvatların 22 Kasım 1995 tarihinde imzaladıkları Dayton Anlaşması bunun en son örneklerinden birini oluşturmaktadır ${ }^{1}$. Uluslararası orgütlerin Bosna-Hersek sorununun çözümüne yönelik girişimleri ve kararları da başta Birleşmiş Milletler Güvenlik Konseyinin kararları ve kurduğu Barış Gücü Kuvvetinin faaliyetlerinden NATO'nun bazı askeri müdahalelerine kadar birçok karar ve girişimi kapsamaktadır. Bu çerçevede Güvenlik Konseyi'nin 21 Şubat 1992 tarihli bir karan ile kurulan Birleşmiş Milletler Koruma Kuvveti (UNPROFOR)'dan başlayarak bugün eski Yugoslavya ülkelerinde belirli silahlı müdahalelere NATO kuvvetleri aracılığıyla olanak sağlayan Banşı Uygulama Kuvvetine (IFOR) kadar birçok ömek göstermek olanaklıdır.

Bosna-Hersek sorununa ilişkin olarak uluslararası hukukun sağladığı üçüncü olanak ise, uluslararası yargı yolları aracılığıyla gerçekleştirilen ya da gerçekleştirilmesine çaba sarfedilen müdahaleler olmaktadir.

\footnotetext{
*A.U. Siyasal Bilgiler Fakültesi, Oğretim Uyesi.

${ }^{1}$ Dayton Anlaşması konusunda bilgi için bkz. D. J. Scheffer, "International judicial intervention," Foreign Policy, No. 102, Spring 1996, s. 42-47.
} 
Bosna-Hersek Sorununa ilişkin olarak ulıslararası yargının rolünü değerlendirebilmek için öncelikl: uluslararası hukukta uluslararası yargının yeri konusunda birtakım genel bilgilırin hatırlatılması yerinde olacaktır.

\section{Uluslararası Hukulkta Uluslararası Yargının Yeri (Genel)}

Uluslararası hukuk günüritïzde de büyüik oblçüde Devletlerarası ilişkileri düzenleyen bir hukuktur. Kişilerin yaşamlıını ın ve haklannın ulyslararası hukukta korunması ve kişilerin işlediği suçlar nedenij le ılıslararası hukukta sorumlu tutulması Ikinci Dünya Savaşından bu yana bazı gelişııeler gớstermekle birlikı bugün de hala kural dışı bir durumu oluşturmaktadır.

Öte yandan, Devletler áras ındaki uyuşmazlıkların bir uluslararası yargı yoluna götürülmesi, iç hukuktaki duruinuuı aksine, uluslararas hukukta zorunlu değildir. Başka bir deyişle, ikili bir uyuşmazlı ș:ın iki tarafı da açıkça ya da herhangi bir kuşkuya yer vermeyecek bir biçimde kabul etr ıediği sürece, bu uy uşmazılığın bir uluslararası yargı organı önüne götürülmesi olanağı yol:tur. Devletler rizaları ile bir uyuşmazlığın belirli bir uluslararası yargı organı öıuin: gcittïrülmesini kabul etliklerinde de, bu uluslararası yargı organı ancak kendisine tanınan yetki ölçüsünde hir davaya bakabilmcktedir. Günümüzde evrensel düzeyde ck:vletlerarası uyuşmazlıłlara bakmakla görevlendirilen tck uluslararası yargı organı La Haye'dlc bulunan Uluslararası A.dalet Divanı'dır. Bu Divan'ın Statüsüne (mad. 34/1) göre, 'kencli nzầlarıyla Divanı y'ethili kıldıklan ölçüde, sadece Devletler Divan önünde bir da'ianın tarafı olabilmektedir. Eaşka bir deyişle, Uluslararası Adalet Divanı önünde uluslara'ası örgütlerir ve kişilerił davalı ya da davacı olma hak ve yetkileri de yoktur.

Kişilerin yaşamlanının ve haklarının korunntası ve kişilerin işlediği suçlar nedeniyle uluslararası düzey'ds: sorumlu tutulmaları ise, Ikinci Dünya Savaşı sonrasında insan haklarının uluslararası diizeyde korunıması ve sqvaş nedeniyle barışa ve insanlığa karşı işlenen suçların failleri ile savaş sırasında işlenerı savaş suçlarının faillerinin cezalandınlması çerçevesinde ılu:ilararası hukuka girntḩ̧̧ir. Kişilerin savaş nedeniyle ve savaş sırasında işledikleri suç lara bağlı olarak uluslararası düzeyde yargılanmaları ve cezalandınimalan ilk kez 08/1)8/194 ؛ iarihli Londra Andlaşması ile kurulan ve Alman savaş suçlularını yargılayan Niiremberğ, Uluslararası Askeri Mahkemesi ${ }^{2}$ ve 19/01/1946 tarihli bir andlaşma ile Tokyo'ila kurulan ve Japon savłs suçlularını yargılayan Uzakdoğu Uluslararası Askeri Mahkemæsi ${ }^{3}$ aracılığıyla gerçek|eşmiştir. Böylece günümüzde de uluslararası hukuka göre, Nüıemburğ ve Tokyo Mahkemeleri için olduğu gibi özel bir uluslararası düzenleme bulunmadlığı sürece, kişilerin iş̧lediği suçlar nedeniyle sorumlu tutulmaları ancak ulusal mahkımeler ïriinde sözkonusu olabilmektedir.

${ }^{2}$ Andlaşma metni için bkz:. Frociss des grands crirninels de guerre devant le Tribunal militaire international (Nuremberg: 14 novembre 1945-1 er octobre 1946) Nuremberg. 1S.47. Tome I, s. 8. Metnin Türķ̧e çevirisi için bkz. N. Poroy, Nüremberg Davan, Ankara, 1948, s. $10-1$ i.

${ }^{3}$ Büyük ölçüde Nurember Mahkemesinden farkları kinusunida bkx. R. K. Woetzel, The Nuremberg trial in international law, London or $N_{i}: w^{\prime}$ York, 2nd. ed., 1962, s. 226-232. 
Çok genel bir biçimde çizdiğimiz bu çerçeve içinde Bosna-Hersek Sorunu gibi hem devletler arasında hem de değişik guruplar arasında birçok uyuşmazlığın ve çatışmanın yaşandığı çok yönlü bir sorunda uluslararası hukukun uluslararası yargı organları aracılığı ile sunabildiği olanaklar da çok sınırlı bulunmaktadır. Bosna-Hersek Sorununda, uluslararası hukukun uluslararası yargı konusuda sunduğu bu sınırlı olanaklardan yararlanılabilmesi bugüne kadar iki çerçevede olanaklı olmuştur. Bunların bir tanesi, Bosna-Hersek Cumhuriyeti'nin 09 Aralık 1948 tarihli Soykınmın Önlenmesi ve Cezalandırılması Sözleşmesine dayanarak 20 Mart 1993 tarihinde Uluslararası Adalet Divanı onünde Yugoslavya'ya karşı bir dava açması olayıdır. Ikincisi ise, B. M. Güvenlik Konseyi'nin 25 Mayıs 1993 tarihli ve 827 sayıl bir karan ile kısaca "Eski Yugoslavya'da Işlenen Suçlar. Için Uluslararası Ceza Mahkemesi" diye adlandıracağımız özel bir Uluslararası Mahkeme kurularak Bosna-Hersek dahil bütün eski Yugoslavya ülkesinde işlenen ağır insancıl hukuk ihlallerinin faillerinin yargılanarak cezalandırılmasının düzenlenmesi olayıdır. Bu her iki Uluslararası Mahkemenin Bosna-Hersek sorununa ilişkin müdahalclerinin başlıca verileri surasıyla ele alınacakur.

\section{Bosna-Hersek Sorununda Uluslararası Adalet Divanı'nın Müdahalesi}

Bosna-Hersek Sorununa Uluslararası Adalet Divani'nın müdahalesi Bosna-Hersek Cumhuriyeti'nin 20 Mart 1993 tarihli bir başvuru ile 1948 tarihli Soykırım Sözleşmesinin IX. maddesine dayanarak Yugoslavya'ya karşı Divan önünde dava açılması ile gerçekleşmiştir ${ }^{4}$. Soykırım Sözleşmesinin IX. maddesi soykırımı yasaklamakta olup bu Sözleşmenin yorumu ve uygulanması konusunda taraf devletler arasında çıkacak uyuşmazlıkların tek-taraflı başvuru yolu da dahil Divan önüne getirilebileceğini öngörmektedir ${ }^{5}$. Yugoslavya'nın eski Yugoslavya Sosyalist Federatif Cumhuriyeti'nin yapı̆̆ı andlaşmalan tanıması ve Bosna-Hersek Cumhuriyeti'nin de eski Yugoslavya'nın ardılı sıfatıyla Soykırım Sözleşmesine taraf olmașına bağlı olarak Bosna-Hersek Cumhuriyeti sorunu Divan'a getirmiştir ${ }^{6}$.

Bosna-Hersek Cumhuriyeti bu başvurusunda özetle Yugoslavya'nın hem Soykırım Sözleşmesinin çeşitli maddelcrini, hem Birleşmiş Milletler Andlaşmasını hem de 1907 La Haye Kara Savaşı Sözleşmesi ile 1949 Cenevre Insancıl Hukuk Sözleşmelerini ve ekli I. sayılı Protokolunu ve Insan Haklan Evrensel Bildirisini çiğnediklerini bildirmekte ve bunlann Divan'ca saptanmasını istemektedir ${ }^{7}$. Aynica, Bosna-Hersek Cumhuriyeti bu başvurusunda Divan'ın Bosna-Hersek'in meşru savunma hakkı bulunduguunu, bu hakkını yalnız ya da ortak meşru savunma ilkesi uyarınca başka Devletlerle birlikte kullanabileceği ve Güvenlik Konseyi'nin 713 sayılı kararıyla eski Yugoslavya ülkeleri için koyduğu silah ambargosunun Bosna-Hersek'in meşru savunma hakkını sınırlayıcı bir biçimde anlaşılmaması gercktiği konulannda hakkını teslim etmesini ve Yugoslavya'nın

${ }^{4}$ ICJ, Application of the Convention on the prevention and punishment of the crime of genocide (Bosnia and Herzegovina v. Yugoslavia (Serbia and Montenegro), 1993, s. 3.

$5_{\text {Sözleşme metni için bkz. R. G., 29.3.1950, Sayı } 7469 .}$

${ }^{6}$ ICJ, Application of the Convention on the prevention and punishment of the crime of genocide (Bosnia and Herzegovina v. Yugoslavia (Serbia and Montenegro), 1993, s. 109-113.

${ }^{7}$ ICJ, Application (aynı yapıt), s. 134-138. 
ya da onun ajanlarinın Bosna-Hersek. v.ttaridaşlanını s sıemli etnik temizliğe tabi tutma uygulamasına, öldürme, işkıncı, t za geçme vb. eylemlerine, kentleri ve halkı bombalama eylemlerine ve Bos,ra-Hér sek'e karşı hareket eden her türlü askeri ya da yarıaskeri örgüt, grup ya da kişiy: silalı. ınihimmat, loj slik destek ve her türlü yardıma hemen son vermesini istemıktzdiı. Bosna-Hersel Cumhuriyeti ayrica Divan'ın Yugoslavya'nın bu konularda v:ardiği t in ıararlar için ţz.minat ödemesi gerektiğine karar vermesi isteminde bulunmaklaadır.

Bosna-Hersek Cumhuri y'eti aynı tarihteki bir başvưusu ile Divan'dan bütün bu konularda Yugoslavya'nın eylimlerire ve Bosna-Herłek'e karşı hareket eden askeri ve yarı-askeri orgüt, grup ya da ksişileıł her türlü yardına hemen son vermesi ve meşru savunma hakkının tanınması ilc l:ınd gerçekleştircbilmek için üçüncü devletlerin kendisine silah, mühimmat ve: asker kuvvet gönderme hakkı bulunduğu konularında hakkını teslim etmesi amacıylk ge jici kı)ruma önlemle ka kaian vermesini istemiştir ${ }^{8}$.

Uluslararası Adalet Divanı Stıı̈ü:üne (mad. 41) göre Divan'a herhangi bir başvuru karşısında eğer kendisinden gy ric i liınıma önlemleri karan alınması istenmişse, Divan öncelikle bu isteği ele almaktı̌ldır Bı nılan sonra da, eğer Divan'ın yargı yetkisine itiraz varsa, Divan ikinci olarak ye:liil: olıp olmadığını incelemekte ve eğer yetkili ise son olarak da davanın esasına ilişkin incelı mıesini yapmakto ve karar vermektedir.

Bu kurallar çerçevesinde B ssın:--..tersek Cumhutiyeti'nin bàşurusu ile ilgili olarak Divan 01-02 Nisan 1993'te gerş̧cklı: tirdiği duruşma ssinunda geçici koruma önlemleri sorununu değerlendirmiş ve $\left(88 \mathrm{Ni}\right.$ ian 1993 'te bu kı̉nudaki kararını açıklamıştır ${ }^{9}$. Uluslararası Adalet Divanı ge:̧ici koru na önlemleri kararında ilk önce, Yugoslavya'nın bazı itirazlannı gözönünde lutaral, kı:s.n kararını sonłaya saklamak koşuluyla, genel bir biçimde bu davada yetkisini dęgerler. rirniş ve yetkis nin yalnızca Soykınım Sözleşmesi ile sınırlı oldugu kararına va arak ò I Sözzleşmenin kapsamı dışındaki istekleri hesaba katmamışur ${ }^{10}$. Böylece, Divaı ö::ellikle Bosna-Hersek Cumhuriyeti'nin meşru savunma hakkı, bunun öteki Devletler! : birlil k: ortak kullanımı ve eski Yugoslavya ülkelerine Güvenlik Konseyi kararlarıjla konulan silah ambargosu konularında hiçbir karara yönelmemiştir. Soykırım Sözlışmıesi h ikümlerinin çiłnenınesine acilen son verilmesine ilişkin olárak ise Divan, önçlik e Yugoslavya' ın soykırım suçu işlenmesinin onlenmesi konusunda elind: clan tü̈tün onlemleti hemen alması gerektiğini ve Yugoslavya'nın yetkisi altındı bulunıın ya da desteğinden yararlanan herhangi bir askeri ya da yan-askeri (paramilitairi: biritr ir ya da dizensił ordu biriminin ve Yugoslavya'nın yeukisi ya da etkisi altında bulumın herhangi bir örgütün ya da kişinin soykırım eyleminde bulunmasını, bunı lısivik etmesini ya da yardımcı olmasını engellemesi gerektiğini karara bağlamışır $"$. Divanı, aynıca, iki tafaf devletin de durumu ağırlaştıncı tutumlar almaktan kaçınmasını kirar virnmiş̧tir.

${ }^{8} \mathrm{Bkz}$. ICJ, Case concerning: application of the Convention on the prevention and punishment of the crime of genocide-Request for the Indication of provisional measures, Order of 8 april 1993, s. 8-9.

${ }^{9}$ ICJ, Request for the indication of provipional measures (ayni yapit), Order of 8. april 1993.

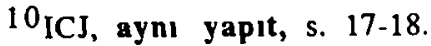

11 ICJ, aynı yapıt, s. 24. 
Uluslararası Adalet Divanı'nun bu geçici onlemler kararına rağmen Bosna-Hersek'te Sırplann soykırım faaliyetlerini sürdürmesi üzerine Bosna-Hersek Cumhuriyeti 27 Temmuz 1993 tarihli bir ikinci başvuru ile yeniden geçici onlemler kararı alınması isteminde bulunmuştur ${ }^{12}$. Bu başvuru ile Bosna-Hersek Cumhuriyeti Divan'dan Yugoslavya'nın Bosna-Hersek'e karşı herhangi bir amaçla askeri, yan-askeri ve düzensiz kuvvetlere, örgütlere ve kişilere hiçbir biçimde yardım etmemesini ve Bosna-Hersek'in ülke bütünlügüne karşıı hiçbir girişimde bulunmamasını istemiş ve ayrıca Yugoslavya'nın soykırım eylemlerinin ónlenmesi için Bosna-Hersek Cumhuriyeti'nin meşru savunma hakkını kullanması hakkı bulunduğuna karar vermesini istemiştir. Bosna-Hersek Cumhuriyeti'nin bu ikinci başvurusu üzerine Yugoslavya Cumhuriyeti de 10 Ağustos 1993 tarihinde aynı Soykırım Sözleşmesine dayanarak Divan'a bir karşı-başvuruda bulunmuş ve özellikle Bosna-Hersek Cumhuriyeti'nin etnik Sırp gruplarına karşı soykırım suçu işlenmesini ơnlemck için elindeki bütün olanakları kullanarak gerekli önlemleri almasına Divan'ın karar vermesini istemiştir ${ }^{13}$.

Uluslararası Adalet Divanı bu iki karşılıklı başvuruyu birleştirerek taraflan 25 Ağustos 1993 tarihinde duruşmaya çağırmıştur. Anılan duruşma 25-26 Ağustos 1993 tarihlerinde yapıldıktan sonra Divan Bosna-Hersek Sorununa ilişkin olarak ikinci geçici koruyucu onlemler kararını 13 Eylül 1993'te açıklamışı ${ }^{14}$. Divan bu kararında da açıkça Soykırım Sözleşmesi kapsamı dışında kalan isteklere ve özellikle Bosna-Hersek ülkesinin bütünlüğüne ve meşru savunma hakkına ilişkin Boşnak isteklerine karşı herhangi bir önlem kararı alamayacă̆ını, buna yetkisi bulunmadığını bildirmiş ve ilk karannda aldığı koruyucu önlemlerin uygulamaya sokulması gerektiğini ifade etmek suretiyle birinci geçici koruyucu önlemler kararını teỵid etmekle yetinmiştir.

Divan 13 Eylül 1993 tarihli geçici koruyucu önlemler kararından sonra 7 Ekim 1993 sayılı bir kararı ile Bosna-Hersek Cumhuriyeti'nin muhtırasını vermesi için 15 Nisan 1994 ve Yugoslavya'nın karşı-muhtırasını vermesi için de 15 Nisan 1995 tarihlerini saptamışıนr ${ }^{15}$. Daha sonra, Yugoslavya'nın karşı-muhtıra verme tarihini 21 Mart 1995 tarihli bir kararı ile 30 Haziran 1995'e uzatan Divan ${ }^{16}$, Yugoslavya'nın 26 Haziran 1995 tarihli karşı-muhtırasında Divan'ın yetkisi ve Bosna-Hersek Cumhuriyeti başvurusunun kabul edilirliği konusunda itirazda bulunması üzerine, Içtüzüğünün 79/3. maddesi uyarınca öze ilişkin incelemesini askaya alarak, Bosna-Hersek Cumhuriycti'ne bu konuda yazılı gözlemlerini bildirmesi için 14 Kasım 1995'e kadar süre tanımışur ${ }^{17}$. Bosna-Hersek Cumhuriyeti'nin yazılı gőzlemlerini sunmasını izleyerek Divan yetkisini ve kabul edilirlik sorununu görüşmek üzere 29 Nisan 1996'da tarậları duruşmaya

$12 \mathrm{ICJ}$. Case concerning application of the Convention on the prevention and punishment of the crime of genocide-Further requests for the indication of provisional measures, Order of 13 september 1993, s. 332.

${ }^{13}$ ICJ, aynı yapıt, s. 334.

${ }^{14} \mathrm{ICJ}$, aynı - yapıt, ózellikle bkz. s. 349-350.

15 ICJ, Case concerning application of the Convention on the prevention and punishment of the crime of genocide, Order of 7 october 1993 s. 471.

${ }^{16}$ ICJ, Communiqué, No. 95/10, 6 april 1995.

17 ICJ, Communiqué, No. 95/21, 19 july 1995. 
çă̆ırmıştır ${ }^{18}$. 29 Nisan ve 3 Mayı: 159,5 tarihlerinde yapıı|lan duruşmaların sonunda Divan 11 Temmuz 1996 tarihi:tile y'skisi ve kabul \&dilirlik konusundaki kararını vermiştir $^{19}$.

Divan 11 Temmuz 1996 larihli $r e t k i$ ve kabul edilebilirlik karannda yetkisini ozellikle kişiler bakımından (ratione p srsonae), konu bakunından (ratione materia) ve zaman bakımından (rationae tein pıris) incelemişti . Divan aynca Bosna-Hersek Cumhuriyeti'nin Yugoslavya'rın Yıgo ilıvya'daki Barıs Için Uluslararası Konferans Hakemlik Komitesi Başkanı'na 8 :azirar, 19!92 de gönderdił̣i bir mektuba atıfla Soykınm Sözleşmesi dışındaki sorunların da ele ål nabileceğini kabul eıtiği yönündeki iddiasını da yetkisini değerlendirirken gözőrüunıle tutmuştur. Divan bu kararında ayrıca Yugoslavya'nın Bosna-Hersek Cumhıriyeti'nin başvurusunun kabul edilebilirliği konusunda ileri sürdüğü gerekçelerini dẹ̆ əslendirmiştir.

Divan, anılan kararına göre, d:?tle Yugoslavya nın 27 Nisan 1992 tarihli bir bild̊iri ile eski Yugoslavya Clınlıuriỵti'nin bütün endlaşmalarını kabul ettiğini açıklaması ve Bosna-Hersek Curnhuriy ti'nin de 22 Majıs 1992'de B.M.'ye kabulü ile Soykırım Sőzleşmesine taraf olable:cị̣:n:n hukuken ortay'a çıkması ve ardıllık yoluyla bu Sözleşmeye başvuru tarihindeı önce l araf olması nedehiyle, kişiler bakımından yetkili olduğu sonucuna varmıştır ${ }^{20}$. Y Jğoslav'ya'nın başyuru tiarihinde Bosna-Hersek Cumhuriyeti'ni tanımadığı, dolayısıyla soykirım Sözleşnısiruin taraflan bağlamayacağı iddiasını değerlendiren Divan, 14 .4ralık. 1595 'te yürürlüğg g giren Dayton-Paris anlaşmaları ile her haliyle tarafların birbirini tanıdı ğı açıklayarak, daha sonra tamamen bir usul eksikliği nedeniyle kendini yeukisiz ilan ı:unessinin gerekmediğini aynca bildirmiştir ${ }^{21}$.

Divan kararında konu bak mırıdar j'ekisini incelediğinde, Yugoslavya'nın BosnaHersek'te bir iç savaş olduğu ‘|klııııs.yla uluslararas bir uyuşmazlık bulunmadığı iddiasını, Soykınm Sözleşmesiı in uj'fulanmasında taraflann karşıt görüşlere sahip olması nedeniyle bir uluslarajası u) u; ;mazlık bulunduğ sonucuna varmıştır ${ }^{22}$. Yugoslavya'nın Soykırım Sủzleşınesinin. IX. maddesinde öngörülen türden bir uluslararası sorumluğun bulunna:ı̈̆g idk iz sını ise anılan maddenin hiçbir tür uluslararası sorumluluğu Sözleşmesinin kapš.mı dı:̣ı ala birakmadığı giosüşüi ile reddetmiştir $^{23}$.

Divan kararında zaman bikırnıılan ise yetkisine rue Sözleşmede ne de DaytonParis anlaşmalan ile hiçbir sınır ge.tirilmediğine karar vermiştir ${ }^{24}$.

Nihayet Divan, Yugosla'y'a'nıı 8 Haziran 1992 tarihli mektubu ile Divan'ın yetkisini genişletici hiçbir tart:şılınaz nitelikli irade ą̧ılklamasında bulunmadığını

\footnotetext{
${ }^{18}$ ICJ, Communiqué, No. 96/3, is fubruary 1996.

${ }^{19}$ ICJ, Communiqué, No. 96/25, 11 jully 1996.

20 ICJ, aynı yapit, s. 4.

21 ICJ, aynı yapit, s. 5.

${ }^{22}$ ICJ, aynı yapıt, s. 5-6.

$23 \mathrm{ICJ}$, aynı yapit, s. 6.

${ }^{24}$ ICJ, aynı yapit, s. 6
} 
bildirerek kendini yalnızca Soykırım Sözleşmesinin IX. maddesi çerçevesinde yetkili kıldıł̆ını belirtmiştir ${ }^{25}$.

Başvurunun kabul edilemez olduğu Yugoslavya iddialarına gelince, iç savaşa ilişkin olarak bazı olaylar sŏzkonusu olsa bile uyuşmazlığın özde bir uluslararası uyuşmazlık olduğu gerekçesi ile Divan birinci iddiayı reddederken, ikinci Yugoslav iddiasını oluşturan Izzetbegoviç'in başvuru tarihinde Cumhurbaşkanı olmadığı halde başvuruyu imzalamıs olmasını ise, başvuru tarihinde B.M.'in lzzetbegoviç'i Cumhurbaşkanı olarak tanıması nedeniyle reddetmiştir ${ }^{26}$. Sonuç olarak Divan kendini Soykırım Sözleşmesinin IX. maddesi çerçevesinde davaya bakmaya yetkili kabul etmiştir.

Divan, daha sonra, 23 Temmuz 1996 tarihli bir karan ile davanın özüne ilişkin olarak Yugoslavya'nın karşı-muhtırasını en geç 23 Temmuz 1997'de sunmasını kararlaştırmışur ${ }^{27}$. Dolayısıyla, dava halen Divan önünde sürmektedir.

\section{Bosna-Hersek Sorununda Özel Olarak Kurulan "Eski Yugoslavya Iç̧in Uluslararası Ceza Mahkemesi"nin Müdahalesi}

Günümüz dünyasında Devletlararası uyuşmazlıklara bakmakla görevli Uluslararası Adalet Divanı benzeri olan ve kişilerin işleyeceği uluslararası suçlara bağlı olarak kişileri yargılamakla görevlendirilen herhangi bir sürckli uluslararası mahkeme bulunmaması nedeniyle Bosna-Hersek'te işlenen insancıl hukuka ve insan haklanna aykırı ağır suçlar nedeniyle suçluların yargılanması için bu konuda özel bir uluslararàsı mahkeme kurulması yoluna gidilmesi gerekmiştir. Bu konuda once bir andlaşma aracılı̆̆ıyla ozzel bir ceza mahkemesi kurulmasının hukuksal açıdan en uygun olacağı düşünülmüştür. Belirtilen amaca yönelik ilk çalışma 28 Eylül 1992 tarihinde AGIK Insancıl Boyut Mekanizması çerçevesinde üç kişilik bir heyetin bir andlaşma taslağı hazırlamakla görevlendirilmesi olmuştur ${ }^{28}$. Anılan heyet 9 Eylül 1993 tarihinde bir özel uluslararası ceza mahkemesi taslağı hazırlayarak AGIK'e sunmuştur ${ }^{29}$. Ancak, eski Yugoslavya ülkelerinde ve özellikle Sırpların bu tür suçları işlemesi ve böyle bir andlaşmaya Yugoslavya'nın taraf olmaması durumunda istenilen amaca erişilemeyeceğinin anlaşılması ilc bu yoldan vazgeçilmiştir. Böylece, sonuçta, uluslararası uygulamada ilk kez olmak üzere B.M. Güvenlik Konseyinin 25.05.1993 tarih ve 827 sayılı bir karanyla "Eski Yugoslavya Ülkesinde 1991'den Itibaren İslenen Uluslararası Insancıl Hukukun Ağır thlallerinden Sorumlu Suç Faillerinin Yargılanması Için Uluslararası Mahkeme" kurulmuştur ${ }^{30}$.

B.Ma Güvenlik Konseyi'nin .ilgili kararının ekini oluşturan Mahkeme Statüsüne göre, bu Mahkeme eski Yugoslavya ülkesinde (dolayısıyla, sadece Bosna-Hërsck'te değil)

25 ICJ, aynı yapit, s. 6 :

${ }^{26}$ ICJ, aynı yapit, s. 6-7.

${ }^{27}$ ICJ, Communiqué, No. 96'26, 24 July 1996.

${ }^{28}$ Corell-Türk-Thune (Rapporteurs), Proposal for an International War Crimes

Tribunal for the Former Yugoslavia, CSCE Moscow Human Dimension Mechanism to Bosnia-Herzegovina and Croatia, 9 february 1993, s. 9.

${ }^{29}$ Aynı yapit, s. 99-139.

${ }^{30}$ UN, Security Council, S/RES/827 (1993), 25 May 1993. 
01 Ocak 1991 tarihinden itibarın 1949 Cenevre Insancıl Hukuk Sőzleşmelerine, genel olarak savaş hukukunun teamül kurallărna, 1948 Soykarım Sözleşmesine ve Nüremberg Mahkemesi kararlarıyla insan iıj̧iı karşı suç oluşturduğu kabul ve anılan Güvenlik Konseyi kararı ile de teyid edilen silahlı çauşmalar sırasında sivillere karşı girişilen oldürme, işkence, köleleştirme, ir za geçme vb. suçlan kapsayan uluslararası kurallara aykın olarak işlenen suçlar kolıusunda yetkili kılınmışır ${ }^{31}$. Mahkeme Statüsüne göre, aynı konularda ulusal mahkemiclerin de yetkili olabilmesi nedeniyle belli bir davayla ilgili olarak hem bir ulusal maihkemenin hem de Uluslararası Mahkemenin kendini yetkili bulması durumunda Uluslararası Mahkemenin yetkisinin üstünlügü kabul edilmekte ve ulusal mahkemenin davaya son vererek bütün bilgi ve belgeleri Uluslararası Mahkemeye aktarması gereknıอk Ledir $^{32}$. Yine aynı Statü, gerek ulusal mahkemelerce gerekse Uluslararası Mahkemęe bir davaya bakılmı̧ ve karar kesinleşmişse, Non bis in idem ilkesi gereğince, bu da'‘ay'a yeniden bakılamayacağını öngörmektedir ${ }^{33}$.

Uluslararası Mahkeme |]. yargııçıan oluşmaktadır ${ }^{34}$. Mahkemenin bir savcılığı bulunup; suç failleri hakkında biligi ve belge toplamak, belli faillerle ilgili soruşturma başlatmak ve gerektiğinde davil açmak bu Savcılığın yetkisindedir ${ }^{35}$. Savcılığın failleri, magdurları ve tanıklan sorgulaıma ve kanıtlan toplama yatkilerini gerektiğinde B.M. üyesi Devletlerin ülkelerinde de ülke devletinin yetkili makamlan ile işbirliği içinde kullanması kabul edilmektedir!'́. Yine, Uluslararası Mahkemeden gelecek istek üzerine devletler faillerin araştırılması 'vi saptanması, kanıtların toplanması, gerekli bilgi ve belgelerin toplanarak Mahkenız'e gionderilmesi vb. konularda Mahkeme ile işbirliği yapma ve yardımlaşmada bı.ılu uma yükümü altındadır 37 . Uluslararası Mahkeme yargılamayı vicahi yapmak zolunda olup, Mahkemenin verecegi failleri yakalamak ve tutuklama kararlannın failin lıulundığu ülke devleti yeutililerince yerine getirilmesi zorunluluğu bulunmaktadir. Liluslararası Mahkemede yargılanarak hüküm giyen suçluların hapis cezalannı bu g:Jrevi yapmaya gơnüllü olán B.M. üyesi devletlerin birinde çekmesi gerekmektedir ${ }^{38}$. Uluslaurirası Mahkeme yargıçlan, savcı ve savcı yardımcıları ve ơteki görevlileri bu görevleri dolayısıyla devletlerde gerekli dokunulmazlık ve ayncalıklardan yararlanacaktır ${ }^{3: !}$

Anılan Uluslararası Malikeme halen La Haye'de kurulmuş olup, 16 Kasım 1993 tarihinden itibaren de görevin:: başlamış bulunmaktadır. Mahkeme savcılığı çeşitli suç faillerini saptamayı, gerekli bi lgi ve belgeyi toplamayı sürdürmekte olup, halen birçok suç failiyle ilgili olarak Małıkene ónünde dava açmış bulunmaktadır. Uluslararası Mahkemenin bu davalarla ilı̣ili bazı yargılamaları sonuçlanmıs olup, yargılamalar sürmektedir.

\footnotetext{
${ }^{31} \mathrm{Mad}$. 2-5.

32 Mad. 9.

33 Mad. 10.

${ }^{34} \mathrm{Mad} .12$.

35 Mad. 16.

${ }^{36}$ Mad. 18-21.

${ }^{37}$ Mad. 29:

$38 \mathrm{Mad} .24$ ve 27.

${ }^{39} \mathrm{Mad}$. 30.
} 


\section{Değerlendirme}

Bu olayların da gösterdiği gibi Bosna-Hersek Sorunu türü krizlerde uluslararası hukukun olanakları Uluslararası Adalet Divanı gibi Devletlerarası yargı organları bakımından değerlendirildiği zaman şu sonuçlarla karşılaşılmaktadır.

Birinci olarak, Uluslararası Adalet Divanı önündeki Bosna-Hersek Cumhuriyeti ile Yugoslavya arasındaki davadan anlaşılacağı gibi, Bosna-Hersek Sorunu gibi hem devletler arasında hem de çok toplumlu devletlerde bu devletlerden birinden sağladığı destek ve yardımlara dayanarak toplumlardan birinin ötekilerini ezmeye ya da yoketmeye yönelik eylemlerine bağlı olarak toplumlar arasında çıkan çatışmalarda ve krizlerde günümüz uluslararası hukuku yalnızca devletler arasında uluslararası yargının çalışırııımasına olanak vermektedir. Böylece, çauşmaların ya da krizlerin en sıcak geçtił̆i toplumlararası çekişmelerde uluslararası yargı bu devletlerden biri üzerinde etki yapmak suretiyle ancak dolaylı olarak bir müdahalede bulunabilmektedir.

Ikinci olarak, uluslararası yargıya gidilmesinin uyuşmazlık tarafı devletlerin nzasını gerektirmesi ve uluslararası yargı organının yetkisinin verilen bu rızanın kapsamı ile sinırı bulunması nedeniyle, bu tür krizlerde birçok onemli sorun için yargı organı yetkisizliğini bildirme zorunda kalmaktadır. Nitekim, Uluslararası Adalet Divanı önünde Bosna-Hersck Cumhuriyetinin açuğı davada görüleceği gibi, Divan bu yetkisinin yalnızca Soykınım Sözleşmesi ile sınırlı kalacağını ve meşru savunma hakkının kullanılması ve ambargoya ilişkin olarak bir karara varmayacağını bildimektedir.

Üçüncü olarak, uluslararası yargının halen uluslararası hukukun uygulanmasında kuraldışı bir yolu oluşturmasına bağlı bulunarak, bu tür yargı organlan gerek yctkilerinin saptanmasında gerekse usulün belirlenmesinde ve uygulanmasında o kadar duyarlı çalışmak zorunda kalmaktadır ki, bu da kaçınılmaz olarak bu tür krizlerin gerektirdiği acil müdahalelerin aksine son derece yavaş işleyen bir yargı mekanizmasını ortaya çıkarmaktadır. Bosna-Hersek Cumhuriyeti-Yugoslavya davasında Divan'ın bugüne kadar,yalnızca geçici koruyucu önlemler kararı ve yetki konusunda karar alabilmesi nedeniyle davanın 1997 sonbaharından önce sonuçlanması olanaklı görünmemekıedir.

Dördüncü olarak, uluslararası yargı organlarının kararlarının uygulanması büyük ölçüde bu kararın muhatabı devletlere kalması ve uluslararası alanda yaptrım uygulayan devletlerdekine benzer bir yaptırım mekanizmasının bulunmaması nedeniyle, bu devletleriń iyi niyetten yoksun tutumları karşısında fiilen bir sonuç alınması bir hayli gecikmeli olmakta ve hatta bazen olanaklı bulunmamaktadır. B.M. Andlaşması 94. maddesinde Uluslararası Adalet Divanı kararlarına uymayan devletlere karşı ilgili oteki devletlerin Güvenlik Konseyi'ne başvurmasını öngörmektedir. Ancak, Bosna-Hersek sorununa ilişkin uygulamanın da gősterdiği gibi, bu tür krizlere müdahalede bazen son derece çekingen davranan bu siyasi organın müdahalelerinin de Divan kararının uygulaturilabilmesi konusunda bir takım kuşkulara yer vermektedir.

Bosna-Hersek Sorunu türü krizlerde uluslararası hukukun olanaklan kişilerin işledikleri suçlar nedeniyle uluslararası düzeyde sorumlu tutulmaları konusunda değerlendirildiğinde ise, genelde, çok daha ümitsiz bir tablo ile karşılaşılmaktadır. Ancak, Bosna-Hersek Sorunu bu ümitsiz tabloya ilişkin olarak birtakım olumlu gelişmelerin konusunu oluşturmuştur. Bu konuda şu sonuçlarla karşılaşılmaktadır:

Birinci olarak, uluslararası düzeyde bu konularda yetkili olan sürckli bir uluslararası mahkemenin bulunmaması nedeniyle olağan olarak kişilerin uluslararası 
yargı organlannca yargılanması olăııał Jı değildir. Ancak, Bo:sna-Hersek Sorunu Güvenlik Konseyi kararı ile kurulan Ulusilararası Mahkeme say'esinde bunun onemli bir kuraldışılı̆̆ını oluşturmaktadır.

Ikinci olarak, büyük ölçiide Bosna-Hersek Sorununa yönelik bir biçimde oluşturulan bu ozel Uluslararası Mahkemenin kurulmas. ile daha once bu konuda tecrübeye sahip olmayan uluslararasi toplum birçok soruna çőzüm bulmak zorunda kalmıştır. Şöyle ki, ilk sorun bijylı: bir Uluslararası Mahkemennin nasıl bir uluslararası hukuk işlemi ile gerçekleştirilec: ğgine ilişkin olmuştur. AGIK çerçevesinde yapılan değerlendirmelerde bunun ancak bir andlaşma ile yapılabilece.ğ kanısı taşınması ve bu yolun çok uzun bir süre alacağırın görlilmesi üzerine, sonuda, çok daha pratik fakat hukuksal açıdan biraz kuşkulu bir yolu ol uşturan B.M. Güvenlik Konseyi kararı ile böyle bir Uluslararası Mahkemenin ku:ılışu gerçekleştirilmişti:. Uluslararası Mahkemenin kurulması ile de sorunlar bitmemişili:. Bijyle bir mahkemenin çalı̧̧abilmesi için gerekli mali olanaklann B.M. çerçevesind: sitğlanması hala tümüylı çißzülmüş değildir. Nihayet, bu tür suçlara ilişkin olarak Ulıı.lararası Mahkemenin çalışabilmesi için devletlerin Mahkeme ile işbirliğinin sağlanaliilmesi için birçok devletin ulusal mevzuatlanını buna uygun olarak düzenlemesi gerel:m.:kıedir ki bu da birçok devlette halen gerçekleştirilmiş değildir.

Üçüncü olarak, Uluslaraıası Mahkemenin gıyapta yargılama yapmasının sakıncalarını gözönünde tutarak, iıııak Mahkeme önüne çıkııılan kişileri yargılamaya yetkili kılınması bugün bile bu Malikenıenin adil sonuçlar verecek bir biçimde çalışıp çalışamayacağı sorununu sordurrıalitadır. Zira, Bosna-Hersck'e yơnelik olarak bu tür suçları işleyenlerin özellikle Sırplar olduğu gözönünde tutulduğunda bu kişilerin Uluslararası Mahkeme onüne getirehilmesi için Yugoslavya Cumhuriyeti'nin ve BosnaHersekli Sırpların Mahkemenin kuralliurına uygun harcket etmeleri ve Mahkeme ile işbirliği yapmaları zorunluluğı vardır. Eğer Uluslararası Mahkemenin istediği suç faillerini Yugoslavya Cumhuriyeti y:kalayıp Mahkemeye sev'ketmezse, Bosna-Hersek'te bulunan Sırp suç faillerini de Bısn:1-Hersek yetkili makamları yakalayıp Mahkemcye sevketmeyi gerçekleştirecek güç ', olaniaklara sahip olmaz:sa, bu Mahkemenin en önemli suç faillerini yargılaması bir hayili zorlaşacak ya da gerçekleşemeyecektir. Ancak, bu sorun da Mahkemenin 23 Ağustiss $1995^{\circ}$ da Belgrad'da bir irtibat bürosu açmasına izin verilmesi suretiyle günümüzde bir şözüm $\mathrm{c}$ bağlanacak izlenimi vermektedir.

Dơrdüncü olarak, Uluslaırarasi Mahkemenin yargılayacağı suç faillerinin belirlenmesinde ve bunun Mahkemeye sevkedilmesinde Mahkeme Savcılığının ne ölçüde siyasi tercihlerden uzak ve objel:ilf olabileceği ve başı H.M. olmak üzere uluslararası toplumun ne ölçüde bunun gerç:klıştirilmesinde Savcılığa yardımcı olacağı sorusuyla karşılaşılmaktadır. Eğer Savcılık taın bir tarafsızlık ve adileite hizmet amacıyla hareket ederse Bosna-Hersek Sorunundil is:ellikle Yugoslav ve Bosna-Hersekli Sirp liderlerin Uluslararası Mahkemeye sevkedi..mesi :sözkonusu olmaktadıs. Bu liderlerin Uluslararası Mahkemeye sevkedilmesi ve y'ar:ilinması siyasi açıdan karara bağlanması zor bir sorun olduğ kadar bunun fiilen sağlanması da bir o kadar zor görünmcktedir. Bununla birlikte, bu konuda da birçok olumlu ggelişmeye tanık olunmaktadır. Örneğin, Bosnalı Sırplann lideri Karadzic hakkında Mahkıme Savcılığınca halen dava açılmış olup, Karadzic'in Mahkeme önüne çıkarılması ile ıł̣̂raşılmaktadır.

Bütün bu veriler karşısınd a uluslararası yargının Bosna-Hersek Sorunu konusunda ne ölçüde etkili olabileceği hala kimi soru işaretleriyle dolu clmasına rağmen, önemli bir yol alındığı da inkar edilemeyecelıtir. 